\title{
STUDI PERBANDINGAN MODERN DRESSING (SALEP TRIBEE) DAN KONVENSIONAL TERHADAP PROSES PENYEMBUHAN LUKA PADA PASIEN POST OPERASI APENDIKTOMI
}

\author{
Vega M. Tusyanawati, Marlin Sutrisna, Tonika Tohri* \\ STIKes Rajawali Bandung, Indonesia \\ *)E-mail: tonikatohri@yahoo.com
}

\begin{abstract}
ABSTRAK
Penelitian ini merupakan studi perbandingan modern dressing (salep tribee) dan konvensional terhadap proses penyembuhan luka pada pasien post operasi apendiktomi. Tujuan: Penelitian ini bertujuan untuk mengetahui pengaruh jenis perawatan luka terhadap penyembuhan luka post operasi apendiktomi. Metode: Desain yang digunakan pada penelitian ini adalah Quasy Experiment posttest-only design. Jumlah sampel sebanyak 18 orang dengan teknik accidental sampling. Pengambilan data dilakukan di Rumah Sakit Dustira Cimahi pada tanggal 19 April 2017-19 Mei 2017. Instrumen penelitian ini adalah lembar observasi penyembuhan luka. Ijin etik untuk penelitian dari STIKes Rajawali. Data dianalisis secara univariate dan bivariate. Hasil: rerata usia kelompok intervensi 29,6 tahun (SD 3,5) sedangkan pada kelompok kontrol 31,1 tahun (SD 3,4). Nilai median penyembuhan luka kelompok intervensi adalah 1,00 dan pada kelompok kontrol 3,00. Hasil analisis lebih lanjut didapatkan nilai $p$-value 0,001. Kesimpulan: Terdapat perbedaan yang bermakna pada proses penyembuhan luka dengan menggunakan perawatan luka konvensional dan modern.
\end{abstract}

Kata kunci: Jenis perawatan luka; post operasi apendektomi

\section{A Comparative Modern Pressing (Tribee Ointment) and Conventional Pressing of Postoperative Wound Healing in Appendectomy}

\section{ABSTRACT}

The research is comparative study between modern dressing (salep tribee) and conventional toward healing process in post appendectomy patients. Objective: This study was to investigate the effect of treatment of postoperative wound healing appendectomy. Method: The design used in this research is Quasi Experiment, with posttest-only design approach. The number of samples were 18 selected with using accidental sampling technique. Collecting data in Dustira Hospital Cimahi between 19 April and 19 May 2017. The instrument of this research is observation form of wound healing. The ethical clearance from STIKes Rajawali Bandung. Data was analyzed with univariate and bivariate analysis. Result: The result shows the mean age of the intervention group was 29.6 years (SD 3.5) whereas in the control group 31.1 years (SD 3.4). The median value of wound healing in the intervention group was 1.00 and in the control group 3.00. Further analysis resulted in a p-value of 0.001. Conclusion: There is a significant difference in the wound healing process using conventional and modern wound care.

Keywords: type of wound care; post-operative appendectomy 


\section{LATAR BELAKANG}

Apendisitis merupakan salah satu kasus kegawatdaruratan di bagian abdomen dengan keluhan utama nyeri perut kanan bawah yang menetap dan bertambah nyeri. Penyakit ini jika tidak mendapatkan penatalaksanaan dapat menimbulkan perforasi dan meningkatkan risiko kesakitan/ kematian (Sander, 2011). Apendisitis akut merupakan salah satu kegawatan bedah yang paling sering, dan apendiktomi termasuk operasi darurat yang paling sering dilakukan di seluruh dunia (Tampi, Sapan, \& Sumangkut, 2016).

Berdasarkan data dari World Health Organization/WHO tahun 2010, angka mortalitas akibat apendisitis adalah 22.000 jiwa dimana populasi laki-laki lebih banyak dibandingkan dengan perempuan dengan angka 12.000 jiwa pada laki-laki dan sekitar 10.000 jiwa pada perempuan (Faridah, 2015). Sama halnya di Amerika Serikat yang menunjukkan bahwa apendisitis merupakan penyebab yang paling umum untuk dilakukannya operasi darurat dari bedah abdomen dan biasanya terjadi pada usia 10-30 tahun (Smeltzer, dkk, 2010).

Apendisitis akut termasuk kasus terbanyak dari akut abdomen, insiden bertambah sesuai umur, dengan puncaknya pada umur 10-30 tahun, ratio laki-laki dibandingkan dengan perempuan pada usia remaja adalah 3:2 dan menjadi 1:1 sesudah usia 25 tahun (Surya, 2006). Kejadian apendisitis di Amerika Serikat memiliki insiden 1-2 kasus per 10.000 anak pertahunnya antara kelahiran sampai umur 4 tahun dan meningkat menjadi 25 kasus per 10.000 anak pertahunnya antara umur 10-17 tahun (Faridah, 2015). Di Indonesia sendiri apendisitis masuk ke dalam peringkat 2 dalam 10 besar penyakit tidak menular penyebab rawat inap pada tahun 2010 setelah penyakit hipertensi (Kementerian Kesehatan Republik Indonesia/Kemenkes

\section{$\mathrm{RI}, 2012)$.}

Kasus Apendisitis akut mampu berkembang menjadi perforasi apendiks yang nantinya dapat mengakibatkan $67 \%$ kematian (Yulianto dkk., 2016). Agar terhindar dari komplikasi apendisitis maka diperlukan tindakan operasi apendiktomi. Apendiktomi merupakan suatu intervensi bedah yang mempunyai tujuan bedah ablative atau melakukan pengangkatan pada bagian tubuh yang mengalami masalah atau mempunyai penyakit (Muttaqin \& Sari, 2009). Ketika operasi dilakukan lebih dini, angka mortalitas akan menurun kurang dari $0,5 \%$ dan penundaan operasi apendiktomi ini dapat menyebabkan rupture organ dan peritonitis resultan (Black \& Hawks, 2014). Namun pembedahan merupakan ancaman potensial dan aktual pada integritas seseorang ketika menghadapinya (Apriansyah, Romadoni, \& Andrianova, 2015).

Perawatan post operasi apendiktomi meliputi monitor tanda vital, menghilangkan/ mengurangi nyeri, mencegah kekurangan volume cairan, mengurangi kecemasan, memberikan gizi yang optimal, mencegah risiko infeksi, dan perawatan luka (Smeltzer, dkk., 2010). Untuk mencegah terjadinya infeksi maka diperlukan perawatan luka post operasi apendiktomi yang tepat. Survei yang dilakukan oleh WHO menunjukkan 5-34\% dari total infeksi nasokomial adalah ILO (Infeksi Luka Operasi) dan bedah abdomen terbukti berisiko 4,46 kali mengalami ILO dibandingkan dengan tindakan bedah lainnya (Haryanti dkk., 2013).

Beberapa faktor penyebab infeksi diantaranya adalah lamanya waktu terbuka setelah kejadian, peningkatan trauma kulit sekitarnya, kontaminasi bakteri, adanya benda asing dan pencucian yang tidak adekuat (Arisanty, 2013). Untuk itu agar angka infeksi tidak meningkat, maka diperlukan perawatan luka untuk mencegah terjadinya infeksi silang (Yusra \& Aprilani, 2015). 
Saat ini teknik perawatan luka yang berkembang adalah perawatan luka konvensional dan modern. Masih banyak perawat yang masih melakukan perawatan luka dengan hanya membersihkan luka dan mengoleskan antiseptik (konvensional). Padahal risiko infeksi perawatan luka konvensional lebih tinggi dari pada perawatan luka modern. Sehingga perawatan luka modern terbukti lebih efektif untuk proses penyembuhan luka dibandingkan dengan metode konvensional (Fata dkk., 2016).

Pada penelitian yang dilakukan oleh Istikomah (2010) tentang perbedaan perawatan luka dengan menggunakan povidone iodine $10 \%$ dan $\mathrm{NaCl} 0,9 \%$ terhadap proses penyembuhan luka pada pasien post operasi prostektomi di ruang Anggrek RSUD Tugurejo Semarang didapatkan hasil adanya perbedaan proses penyembuhan luka yang signifikan antara pasien post operasi prostektomi yang diberikan perawatan luka dengan menggunakan povidone iodine 10\% dan $\mathrm{NaCl} 0,9 \%$. Dalam hal ini povidone iodine $10 \%$ lebih baik dari $\mathrm{NaCl} 0,9 \%$ dalam penyembuhan luka post operasi prostektomi.

Sedangkan penelitian yang dilakukan oleh Handayani (2016) tentang studi meta analisis perawatan luka kaki diabetes dengan modern dressing mengatakan bahwa metode perawatan luka modern dengan menggunakan prinsip moisture balance lebih efektif dibandingkan metode konvensional. Selain itu penelitian yang dilakukan Ismail, Irawati, \& Haryati (2009) tentang penggunaan balutan modern memperbaiki proses penyembuhan luka diabetik mengatakan bahwa balutan modern mempunyai tingkat perkembangan luka yang lebih baik dibandingkan dengan menggunakan balutan konvensional.

Pada penelitian sebelumnya yang dilakukan oleh Handayani bahwa perawatan luka modern dressing diberikan pada pasien luka kronis (diabetikum), sehingga perlu dilakukan penelitian ulang yang diberikan pada pasien luka akut (post apendiktomi) dengan menggunakan salep tribee untuk melihat proses penyembuhan luka setelah diberikan modern dressing (salep tribee) dan membandingkan dengan perawatan luka konvensional.

\section{METODE}

Desain penelitian ini menggunakan quasi experiment posttest only design. Sampel dalam penelitian berjumlah 18 orang, dengan terbagi dalam kelompok intervensi 9 orang dan kelompok kontrol 9 orang secara accidental sampling. Kriteria inklusi adalah pasien dewasa post operasi appendectomy akut tanpa komplikasi, tidak memiliki penyakit diabetes mellitus. Penelitian ini dilakukan di Rumah Sakit Dustira Cimahi pada 19 April sampai dengan 19 Mei 2017.

Pada penelitian ini dilakukan intervensi dengan menggunakan perawatan luka dengan modern dressing (salep tribee) dan perawatan luka konvensional menggunakan iodine povidone $10 \%$ sebagai kelompok kontrol. Perawatan luka dilakukan oleh perawat yang memiliki sertifikat pelatihan luka modern dressing (bersertifikat CBWT atau CWCC). Hari ke-4 setelah dilakukan perawatan luka, kemudian luka dilakukan observasi yang dilakukan oleh peneliti yang didampingi oleh perawat dengan menggunakan lembar observasi/checklist yang terdiri dari pernyataan tumor, rubor, calor, dolor, dan fungsiolaesa.

Analisis data dilakukan dengan menilai score total dari hasil observasi luka baik pada kelompok intervensi maupun kelompok kontrol dengan melihat nilai rerata, median, standar deviasi, kemudian analisis lebih lanjut dilakukan dengan menggunakan uji alternatif non parametrik Mann-Whitney dengan sebelumnya melakukan uji normalitas data. Etika 
penelitian dilakukan melalui uji klinis oleh STIKes Rajawali.

\section{HASIL}

Hasil penelitian menunjukkan bahwa total pasien yang didapatkan dalam penelitian ini adalah 18 orang. Karakteristik responden berdasarkan usia dan jenis kelamin ditampilkan di Tabel 1.
Berdasarkan tabel 2, skor/nilai penyembuhan luka pada perawatan luka konvensional adalah 2,89 sedangkan pada modern dressing 1,33.

Tabel 1. Karakteristik responden berdasarkan usia

\begin{tabular}{|c|c|c|c|c|c|c|}
\hline \multirow[b]{2}{*}{ Karakteristik } & \multicolumn{3}{|c|}{ Intervensi } & \multicolumn{3}{|c|}{ Kontrol } \\
\hline & $\mathbf{n}$ & mean (SD) & $\%$ & $\mathbf{n}$ & mean (SD) & $\%$ \\
\hline Usia (tahun) & 9 & $29,6(3,5)$ & & 9 & $31,1(3,4)$ & \\
\hline Jenis & & & & & & \\
\hline kelamin: & 9 & & & 9 & & \\
\hline Laki-laki & & 4 & 44,4 & 4 & & 44,4 \\
\hline Perempuan & & 5 & 55,6 & 5 & & 55,6 \\
\hline
\end{tabular}

Tabel 2. Distribusi nilai penyembuhan luka pada kelompok perawatan luka modern dan konvensional

\begin{tabular}{llcc}
\hline \multicolumn{1}{c}{ Variabel } & $\mathrm{n}$ & Min-Maks & Median \\
\hline $\begin{array}{l}\text { Nilai penyembuhan luka pada perawatan luka } \\
\text { modern }\end{array}$ & 9 & $1-2$ & 1,00 \\
\hline $\begin{array}{l}\text { Nilai penyembuhan luka pada perawatan luka } \\
\text { konvensional }\end{array}$ & 9 & $2-4$ & 3,00 \\
\hline
\end{tabular}

Hasil uji normalitas data didapatkan score penyembuhan pada jenis perawatan luka modern 0,000 dan score penyembuhan luka pada jenis perawatan luka konvensional 0,055 . Hasil transformasi data menunjukkan distribusi data tidak normal, maka analisis bivarit membandingkan nilai median penyembuhan luka pada kelompok intervensi dan kontrol. 
Tabel 3. Perbedaan jenis perawatan luka terhadap penyembuhan luka pada kelompok perawatan luka modern dan konvensional

\begin{tabular}{|c|c|c|c|c|}
\hline Kelompok & $\mathrm{n}$ & $\begin{array}{c}\text { Mean } \\
\text { rank }\end{array}$ & D & p-value \\
\hline $\begin{array}{l}\text { Kelompok } \\
\text { intervensi } \\
\text { dengan } \\
\text { perawatan luka } \\
\text { modern }\end{array}$ & 9 & 5,50 &, 500 & 0,001 \\
\hline $\begin{array}{l}\text { Kelompok } \\
\text { kontrol dengan } \\
\text { perawatan luka } \\
\text { konvensional }\end{array}$ & 9 & 13,50 & ,782 & \\
\hline
\end{tabular}

Hasil analisis dengan menggunakan uji Mann-Whitney didapatkan nilai $p$ value $=0,001$ dimana $p<0,05$, artinya terdapat perbedaan yang bermakna antara perawatan luka konvensional dan modern dressing (salep tribee).

\section{DISKUSI}

\section{Nilai Penyembuhan Luka pada Kelompok Perawatan Luka Modern dan konvensional}

Hasil penelitian penyembuhan luka post operasi apendiktomi pada kelompok perawatan luka konvensional hari ke-4 post operasi mengalami penyembuhan luka terganggu dengan nilai rerata 2,89. Sedangkan nilai penyembuhan luka pada kelompok perawatan luka modern dan perawatan standar pada pasien post operasi apendiktomi di RS Dustira Cimahi memiliki nilai penyembuhan luka yang lebih baik dibandingkan dengan perawatan luka konvensional dengan rerata nilai penyembuhan luka 1,33 . Nilai tersebut kurang bagus untuk dikatakan bahwa perawatan luka baik, namun jika dibandingkan dengan perawatan luka konvensional, perawatan luka modern lebih baik. Hal tersebut sejalan dengan literatur yang mengatakan dengan perawatan luka modern dapat mempertahankan kondisi lembab, mengontrol kejadian infeksi, mempercepat penyembuhan luka, mengabsorpsi cairan luka yang berlebihan, membuang jaringan mati, nyaman digunakan, steril dan cost-effective (Arisanty, 2013).

Luka akut (luka post operasi) dapat sembuh atau menutup sesuai dengan waktu penyembuhan luka fisiologis (Arisanty, 2013). Luka dapat sembuh apabila luka tersebut dapat melewati reaksi radang (fase inflamasi) yang tujuan utamanya untuk menggabungkan kembali bagian luka dan mengembalikan fungsinya (Sabiston, 1995). Fase inflamasi merupakan reaksi tubuh terhadap luka yang dimulai setelah beberapa menit dan berlangsung selama 3 hari setelah cedera. Proses perbaikan luka terdiri dari hemostasis (mengontrol perdarahan), mengirim darah dan sel ke area yang mengalami cedera (inflamasi), dan membentuk sel-sel epitel pada tempat cedera (epitalialisasi). Selama proses hemostasis, pembuluh darah yang cedera akan mengalami konstriksi dan trombosit akan berkumpul untuk menghentikan perdarahan. Bekuan darah akan membentuk matriks fibrin yang nantinya akan menjadi kerangka untuk perbaikan sel. Jaringan yang rusak dan sel mast mensekresi histamin, yang menyebabkan vasodilatasi kapiler di sekitarnya dan mengeluarkan serum dan sel darah putih ke dalam jaringan rusak. Hal tersebut akan menimbulkan kemerahan, edema, hangat dan nyeri lokal. Leukosit akan mencapai luka dalam beberapa jam. Leukosit utama yang bekerja pada luka adalah neutrofil yang akan memakan bakteri dan debris yang kecil. Neutrofil akan mati dalam beberapa hari dan akan meninggalkan eksudat enzim yang akan menyerang bakteri atau membantu perbaikan jaringan (Potter \& Perry, 2006). 


\section{Analisis Perbedaan Jenis Perawatan Luka Terhadap Penyembuhan Luka pada Kelompok Intervensi dan Kelompok Kontrol}

Hasil penelitian ini menunjukkan perbedaan bermakna dalam proses penyembuhan luka dengan menggunakan perawatan luka modern dan konvensional. Hal ini karena migrasi epidermal pada luka superficial lebih cepat pada suasana lembab daripada kering. Balutan modern ini berfungsi untuk melindungi luka dari kontaminasi kuman dan mencegah masuknya kuman. Balutan ini memberikan kondisi lembap yang seimbang, yaitu jika luka kering dapat dihidrasi dan jika basah dapat diserap cairannya selain itu dapat membantu memperlancar aliran darah dan vasodilatasi yang berlebih dapat membantu memperlancar aliran darah dan vasodilatasi pembuluh darah sehingga oksigenasi dan alian darah ke luka dapat difasilitasi dengan baik. Balutan ini sangat nyaman dan costeffective bagi pasien (Arisanty, 2013).

Hasil penelitian ini sesuai dengan penelitian yang dilakukan oleh Purnomo, Dwiningsih, \& Lestari (2014) yang menyebutkan bahwa kelompok yang menggunakan perawatan luka modern lebih efektif dibandingkan dengan penggunaan perawatan luka konvensional dengan $p$-value 0,000 . Perawatan luka modern dressing memberikan suasana lembab pada luka yang menyebabkan migrasi epidermal yang lebih cepat dibandingkan dengan suasana kering pada luka. Selain itu perawatan luka lembab akan menurunkan infeksi lebih besar dibandingkan menggunakan perawatan luka kering. Suasana lembab dapat meningkatkan migrasi sel epitel ke pusat luka dan melapisinya sehingga luka lebih cepat sembuh (Purnomo, Dwiningsih, \& Lestari, 2014).

Selain itu, Nontji, Hariati \& Arafat (2015) menyebutkan terdapat signifikansi kolerasi antara teknik perawatan luka modern terhadap kadar interkulin 1 dan interkulin 6 daripada menggunakan teknik rawat luka konvensional dengan $p$-value 0,00 . Hasil tersebut terjadi karena proses penyembuhan luka dipengaruhi faktor pertumbuhan dan sitokin (IL-1 dan IL-6). Hal tersebut akan dirangsang oleh pembalutan luka, teknik pembalutan luka modern yang digunakan dapat menyerap luka drainase, non adhesif, dan debridement autolitik.

\section{SIMPULAN}

Rerata nilai penyembuhan luka setelah diberikan perawatan luka modern yaitu 5,50 sedangkan nilai rerata penyembuhan luka setelah diberikan perawatan luka konvensional yaitu 13,50. Terdapat perbedaan yang bermakna pada proses penyembuhan luka dengan menggunakan perawatan luka konvensional dan modern pada pasien post operasi apendektomi di RS Dustira Cimahi.

Bagi Pasien post operasi apendiktomi disarankan untuk memilih jenis perawatan luka modern dalam perawatan lukanya, hal ini dapat meringankan komplikasi dan mempercepat lama hari rawat sehingga biaya untuk rawat hari menjadi lebih murah dan bagi Rumah Sakit Dustira Cimahi disarankan untuk menyediakan balutan modern/salf modern dressing untuk mempermudah pasien dalam mendapatkan dan menggunakannya. Bagi perawat disarankan untuk menjadi ruangan dengan visi dan misi yang unggul dalam perawatan luka, terutama pada perawatan luka dengan konsep modern dressing. Bagi peneliti selanjutnya, diharapkan menjadi Evidence Based Nursing (EBN) dalam melakukan penelitian selanjutnya terutama untuk mengontrol faktor yang memengaruhi penyembuhan luka (bias) seperti nutrisi, obesitas, merokok, obat-obatan, radiasi, dan stress. 


\section{DAFTAR PUSTAKA}

Apriansyah, A., Romadoni, S., \& Andrianovita, D. (2015). Hubungan antara tingkat kecemasan preoperasi dengan derajat nyeri pada pasien post sectio caesarea di rumah sakit muhammadiyah palembang. Jurnal Keperawatan Sriwijaya, 2(1): 1-9.

Arisanty, I. P. (2013). Konsep dasar manajemen perawatan luka. Jakarta: EGC.

Black, J. M., \& Hawks, J. H. (2014). keperawatan medikal bedah: manajemen klinis untuk hasil yang diharapkan, edisi 8 buku 2. Singapore: Elsevier.

Faridah, V. N. (2015). Penurunan tingkat nyeri pasien post op apendisitis dengan teknik distraksi nafas ritmik. Surya, 7(02): 68-74.

Fata, U. H., Rahmawati, A., Wulandari, N., Fanani, Z., \& prayogi, B. (2016). Pusat perawatan luka Patricia care Blitar unit pelayanan perawatan luka, konseling, produk salep luka dan pelatihan luka. Jurnal Dedikasi: 9-15.

Handayani. (2016). Studi Meta Analisis Perawatan Luka Kaki Diabetes Dengan Modern Dressing. Journal The Indonesian Journal of Health Science, 6(2).

Haryanti, L., Pudjiadi, A. H., Irfan, E. K., Thayed, A., Amir, I., \& Hegar, B. (2013). Prevelensi dan faktor risiko infeksi luka operasi pasca bedah. Sari Pediatri, 15(4): 207-212.

Ismail, D. D., Irawati, D., \& Haryati, T. S. (2009). penggunaan balutan modern memperbaiki proses penyembuhan luka diabetik. Jurnal Kedokteran Brawijaya, 16(1): 32-35. Istikomah, N. (2010). Perbedaan Perawatan Luka Dengan Menggunakan Povodine lodine 10\% Dan $\mathrm{NaCl}$ 0,9\% Ter- hadap Proses Penyembuhan Luka Pada Pasien Post Operasi Prostatektomi Di Ruang Anggrek RSUD Tugurejo Semarang. Retrieved from http://eprints.undip.ac.id/10724/

Kementerian Kesehatan Republik Indonesia. (2012). Buletin jendela data dan informasi kesehatan. Jakarta: Kemenkes RI.

Muttaqin, A., \& Sari, K. (2009). Asuhan keperawatan periopratif: Konsep, proses dan aplikasi. Jakarta: Salemba Medika.

Nontji, W., Hariati, S., \& Arafat, R. (2015). Teknik perawatan luka modern dan konvensional terhadap kadar interkulin 1 dan interkulin 6 pada pasien luka diabetik. Jurnal Ners, 10(10): 133-137.

Purnomo, S. E., Dwiningsih, S. U., \& Lestari, K. P. (2014). Efektifitas penyembuhan luka menggunakan $\mathrm{NaCl} 0,9 \%$ dan hidrogel pada ulkus diabetes melitus di RSU Kota Semarang. Prosiding Konferensi Nasional II PPNI Jawa Tengah, 144-152.

Potter \& Perry. (2010). Fundamental of nursing. $7^{\text {th }}$ ed. Elsevier: Singapore.

Sabiston, D.C. (1995). Buku Ajar Bedah: Bagian II. Jakarta: EGC.

Sander, M. A. (2011). Apendisitis akut: Bagaimana seharusnya dokter umum dan perawat dapat mengenali tanda dan gejala lebih dini penyakit ini?. Jurnal Keperawatan Universitas Muhammadiyah Malang: 15-20.

Smeltzer, S. C., Bare, B. G., Hinkle, J. L., \& Cheever, K. H. (2010). Brunner \& Suddarth's, textbook of medicalsurgical nursing, twelfth edition. Philadelphia: Lippincott Williams \& Wilkins.

Surya, B. (2006). Peran C-reaktive protein (CRP) dalam menentukan diagnosa apendisitis akut. Majalah Kedokter- 
an Nusantara, 39(3): 205-208.

Tampi, H. M., Sapan, H. B., \& Sumangkut, R. M. (2016). Hubungan kadar fibrinogen dengan apendisitis akut. Jurnal Biomedik (JBM), 8(2): 83-87. Yulianto, F. A., Sakinah, R.K., Kamil, M. I., \& Wahono, T. Y.K. (2016). Faktor prediksi perforasi apendiks pada penderita apendisitis akut dewasa di RS Al-ihsan kabupaten Bandung periode 2013-2014. Global Medical Health Communication, 4(2): 114120.

Yusra, S. \& Aprilani, I.(2015). Perawatan luka kaki diabetik pada pasien diabetes mellitus di cindara wound care center Jepara. Jurnal Profesi Keperawatan: 117. 